\title{
Editorials
}

\section{Progress through cooperation: securing a sound training pathway for perioperative transesophageal echocardiography}

\author{
Barry A. Finegan MB FFARCS(I) FRCPC
}

$\mathrm{T}$ HE publication of the "Canadian guidelines for training in adult perioperative transesophageal echocardiography" in this issue of the Journal represents a major achievement for the Canadian Perioperative Echocardiography Group and for the subspecialty of cardiac anesthesiology in Canada. ${ }^{1}$ The document is an honest effort, by those involved, to provide guidance on a practical training program for anesthesiologists wishing to use transesophageal echocardiography (TEE) in routine clinical practice, and given the diversity of training of those currently performing intraoperative TEE in Canada, is more than timely. ${ }^{2}$ The authors sought and received input from the Canadian Society of Echocardiography and the wider membership of the Cardiovascular and Thoracic Section of the Canadian Anesthesiologists' Society, thereby ensuring diversity of opinion, an essential requirement in guideline development. ${ }^{3}$

Intraoperative TEE is an integral component of surgical cardiac care and has wide application perioperatively. ${ }^{4-6}$ The performance of the examination is operator-dependent and demands technical skill as well as the ability to instantaneously interpret information obtained and pursue additional images as indicated by the findings observed. Interpretation of TEE acquired images and placing them in the appropriate context is crucial to assure a correct diagnosis and subsequent management plan. This involves not simply offering a diagnosis to our surgical colleagues, but also providing an opinion as to the appropriate intervention to take, or perhaps more importantly, not to take, in a specific situation. This consultative role can only be exercised with confidence and competence if those offering it are appropriately trained. In 1987, the American Society of Echocardiography published training guidelines directed at cardiologists outlining the components of a comprehensive echocardiographic clinical examination, the core knowledge base, the suggested duration of training duration leading to each level of expertise in the modality, and the experience and training required of those supervising trainees. $^{7}$ Subsequently, patterned on the latter document, specific recommendations were developed for TEE. ${ }^{8}$ In cooperation with the Society of Cardiovascular Anesthesiologists, training guidelines were developed specifically addressing perioperative TEE. ${ }^{9}$ The Canadian guidelines extend the expected proficiency of an individual trained at a basic level to include limited diagnostic abilities, specifically, recognition of valvular heart lesions, intra-cardiac masses and pericardial effusions of significance. This is a sensible recognition of the expertise one would realistically expect of a specialist physician who undertakes three months of dedicated training in TEE and is supported by research aimed at assessing how rapidly physicians can master basic echocardiographic skills. In a prospective, observational, educational study, emergency medicine (ER) residents (PGY 1-3) completed a written and practical examination assessing their knowledge on how to complete and interpret a goal-directed transthoracic echocardiogram (TTE) immediately prior and subsequent to a five-hour didactic session and one-hour proctored practical echocardiographic training session developed by an ER ultrasound director and a cardiologist. ${ }^{10}$ Significant improvements in correct written test scores (from $54 \%$ pre to $94 \%$ post) and capacity to

From the Department of Anesthesiology and Pain Medicine, University of Alberta, Edmonton, Alberta, Canada.

Address correspondence to: Dr. B.A. Finegan, Department of Anesthesiology and Pain Medicine, 8-120 Clinical Sciences Building,

Edmonton, Alberta T6G 2G3, Canada. Phone: 780-407-8887; Fax: 780-407-3200; E-mail: chassist@ualberta.ca 
perform an appropriate goal-directed TTE (from 56\% pre to $94 \%$ post) were observed. A prospective study assessing the ability of medical residents to learn how to effectively perform and interpret TTE at the bedside following a brief didactic and practical instruction session demonstrated that such skills could be acquired rapidly. ${ }^{11}$ Hand-carried cardiac ultrasonography used as a supplement to routine physical examination, even in the hands of relatively inexperienced individuals, can add significantly to diagnostic accuracy. ${ }^{12}$

Ultrasound imaging equipment is now relatively inexpensive, widely available and portable. Anesthesiologists not involved in cardiovascular anesthesia routinely use ultrasonography to facilitate localization of nerve bundles during regional anesthesia and catheter placement. Consequently, exposure to ultrasound imaging occurs throughout residency training. Canadian residents seem eager to obtain further training in echocardiography, with $40 \%$ expressing a desire to take such training as an alternative to engaging in research related activity. ${ }^{13}$ Although not addressed by Béique et al., ${ }^{1}$ there is clearly a need for inclusion of structured echocardiographic training within our residency programs and a mechanism for acknowledgement of such training subsequent to successful completion of residency.

The proposed continuing medical education (CME) and maintenance of competence guidelines are reasonable and achievable by most practitioners in academic centres. In the absence of a critical mass, physicians in smaller non-academic centres will be challenged to meet peer review expectations. Echocardiographyrelated CME relevant to anesthesiologists is not widely available in Canada and one is hopeful that the publication of the guidelines will act as stimulus to the provision of such CME opportunities for Canadian anesthesiologists in an easily accessible manner.

The guidelines address the issue of TEE training and "encourage" training in TTE. If anesthesiologists are to contribute meaningfully to the development of echocardiography, then comprehensive training, particularly of those in educational leadership roles, in all aspects of the modality, including TTE, is distinctly advantageous. One of the most exciting recent developments in the field, three dimensional (3D) echocardiography, is by and large, confined to TTE acquired images. ${ }^{14}$ With time, 3D imaging will be routinely available from the esophageal window and will form a very useful adjunct to our current menu of images, particularly in the assessment of mitral valve pathology. ${ }^{15}$ Optimally, anesthesiologists intending to supervise those training in echocardiography should be exposed to such novel applications of the technology and be the leaders in introducing relevant advances into perioperative practice. This requires that time be spent in a cardiology-directed echocardiography laboratory. Training in the latter environment offers particular advantages, including exposure to a high volume and varied TTE practice and insight into the decision-making process which directs a patient toward a surgical intervention rather than continued observation. Furthermore, collegial relationships between cardiologists and anesthesiologists are fostered by this approach, which are of great value in the ongoing development of a perioperative TEE service.

The blurring of the borders of specific disciplines in medicine and the requirement of physicians to continually adapt and engage in skill development is exemplified by the evolution of ultrasound imaging. We are very fortunate that in the case of echocardiography, a collaborative and mutually respectful relationship has existed between cardiologists and anesthesiologists, as exemplified by the training guideline document in this issue. This response to new opportunities and challenges clearly offers the best outcome for all concerned, especially our patients.

\section{Le progrès par la coopération : con- crétiser l'accès à une formation solide sur l'échocardiographie transœsophagienne péri- opératoire}

Dans le présent numéro du Journal, la publication des "Canadian guidelines for training in adult perioperative transesophageal echocardiography» représente un accomplissement majeur pour le Canadian Perioperative Echocardiography Group et pour la sousspécialité de l'anesthésiologie cardiaque au Canada. ${ }^{1}$ C'est un effort louable qui vise à fournir l'orientation sur un programme de formation pratique pour les anesthésiologistes désireux d'utiliser l'échocardiographie transœsophagienne (ETO) en pratique régulière. 
Étant donné la formation diversifiée de ceux qui utilisent couramment l'ETO peropératoire au Canada, l'initiative est plus que pertinente. ${ }^{2}$ Les auteurs ont demandé et reçu des suggestions de la Canadian Society of Echocardiography et d'une plus importante organisation, la Cardiovascular and Thoracic Section de la Société canadienne des anesthésiologistes, s'assurant ainsi d'une pluralité d'opinions, une nécessité dans le développement de lignes directrices. ${ }^{3}$

L'ETO peropératoire est une composante intégrale de la chirurgie cardiaque et a une vaste application périopératoire. ${ }^{4-6}$ La performance de l'examen dépend de l'opérateur et exige des compétences techniques et l'habileté d'interpréter instantanément l'information obtenue et de rechercher des images additionnelles à partir des données observées. L'interprétation des images acquises avec l'ETO et la capacité de les intégrer dans le contexte approprié sont des éléments cruciaux du bon diagnostic et du plan thérapeutique subséquent. Il faut donc non seulement offrir un diagnostic à nos collègues chirurgiens, mais aussi fournir une opinion sur l'intervention pertinente à faire, ou peut-être plus important encore, à ne pas faire dans une situation bien spécifique. Ce rôle consultatif ne peut être exercé qu'avec confiance et compétence par des personnes adéquatement formées. En 1987, l'American Society of Echocardiography a publié un guide de formation pour les cardiologues soulignant les composantes d'un examen échocardiographique clinique détaillé, les connaissances fondamentales, la durée de la formation suggérée menant à chacun des niveaux d'expérience de la technique et l'expérience et la formation requises par ceux qui supervisent les résidents. ${ }^{7}$

Par la suite, calquées sur le précédent document, des recommandations spécifiques ont été élaborées pour l'ETO. ${ }^{8}$ En collaboration avec la Society of Cardiovascular Anesthesiologists, des lignes directrices pour la formation ont été développées traitant spécifiquement de l'ETO. ${ }^{9}$ Les lignes directrices canadiennes ajoutent aux compétences attendues d'une personne formée à un niveau de base des habiletés diagnostiques limitées, en particulier, la reconnaissance des lésions cardiaques valvulaires, des masses intracardiaques et des épanchements péricardiques significatifs. C'est une reconnaissance importante de l'expérience à laquelle on peut s'attendre, de façon réaliste, d'un médecin spécialiste qui suit trois mois de formation dédiés à la pratique de l'ETO et qui est appuyé par une recherche dont le but est d'évaluer à quel rythme des médecins peuvent en arriver à maîtriser les techniques de base de l'échocardiographie. Dans une étude prospective, observationnelle et d'éducation, des résidents de première à troisième année en médecine d'urgence (MU) ont participé à un examen écrit et pratique qui évaluait leurs connaissances sur la manière de réaliser et d'interpréter un échocardiogramme transthoracique (ETT) immédiatement avant, puis après, une session didactique de cinq heures et une session supervisée d'une heure de formation pratique à l'échocardiographie élaborée par un directeur d'échographie de MU et par un cardiologue. ${ }^{10}$ Des améliorations significatives des scores aux examens écrits (de $54 \%$ en pré-session à $94 \%$ en post-session) ont été observées. Une étude prospective évaluant l'habileté de résidents de médecine à apprendre comment réaliser et interpréter efficacement l'ETT au chevet du malade à la suite d'une brève session de formation didactique et pratique a démontré que les aptitudes peuvent s'acquérir rapidement. ${ }^{11}$ L'échographie cardiaque avec un appareil portatif utilisé comme un supplément à l'examen physique habituel, même entre les mains de personnes relativement inexpérimentées, peut contribuer significativement à la justesse du diagnostic. ${ }^{12}$

Le matériel d'échographie coûte relativement peu maintenant, est largement offert et est portatif. Les anesthésiologistes non concernés par l'anesthésie cardiovasculaire utilisent régulièrement l'échographie pour localiser plus facilement des faisceaux nerveux pendant l'anesthésie régionale et la mise en place d'un cathéter. Par conséquent, l'exposition à l'échographie se fait pendant la résidence. Les résidents canadiens semblent intéressés à obtenir une formation plus poussée en échocardiographie, car $40 \%$ d'entre eux ont exprimé le désir de suivre cette formation plutôt que de s'engager dans une activité reliée à la recherche. ${ }^{13}$ Quoique le sujet ne soit pas abordé par Béique et coll. ${ }^{1}$ il existe très certainement un besoin d'inclure une formation échocardiographique structurée à nos programmes de résidence et un mécanisme de reconnaissance de cette formation subséquente aux études de résidence terminées avec succès.

La formation médicale continue (FMC) proposée et les lignes directrices pour le maintien des compétences sont raisonnables et peuvent être suivies par la plupart des praticiens des centres universitaires. En l'absence d'une masse critique, les médecins de petits centres non universitaires seront confrontés aux exigences du jugement des pairs. La FMC pertinente en échocardiographie pour les anesthésiologistes n'est pas très accessible au Canada et on peut espérer que la publication des lignes directrices stimulera la mise sur pied d'une formation semblable et facile d'accès.

Les lignes directrices traitent de la question de la formation à l'ETO et «encouragent» la formation 
en ETT. Si les anesthésiologistes veulent contribuer significativement à l'essor de l'échocardiographie, une formation complète, surtout pour ceux qui sont actifs dans l'enseignement, dans tous les aspects de la modalité, dont l'ETT, est particulièrement avantageuse. L'un des progrès récents les plus enthousiasmant dans le domaine, l'échocardiographie en trois dimensions (3D), est généralement confiné aux images acquises par ETT. ${ }^{14}$ Avec le temps, l'imagerie en $3 \mathrm{D}$ sera régulièrement accessible par une fenêtre œsophagienne et formera un complément très utile à notre menu actuel d'images, surtout dans l'évaluation de pathologies de la valvule mitrale. ${ }^{15}$ De façon optimale, les anesthésiologistes qui pensent superviser la formation en échocardiographie doivent être exposés aux nouvelles applications de la technologie et être à l'avant-garde en intégrant les nouveautés appropriées à la pratique périopératoire. La situation exige de passer du temps dans un laboratoire d'échocardiographie dirigée par la cardiologie. La formation y présente des avantages particuliers, dont l'exposition à un grand volume de patients et à une pratique variée de l'ETT et un aperçu du processus de prise de décision qui amène à suggérer une intervention chirurgicale plutôt qu'une observation continue. De plus, les relations collégiales entre les cardiologues et les anesthésiologistes sont favorisées par cette approche, ce qui représente une grande valeur dans le développement en cours d'un service d'ETT périopératoire.

Les frontières floues de disciplines médicales spécifiques et la nécessité pour les médecins de s'adapter continuellement et de s'engager dans la construction d'habiletés sont authentifiées par l'évolution de l'échographie. Nous avons la chance, dans le cas de l'échocardiographie, de vivre une relation de collaboration et de respect mutuel entre cardiologues et anesthésiologistes, comme le montre le document sur les lignes directrices de la formation. Cette réponse à de nouvelles réalités et à de nouveaux défis offre clairement le meilleur dénouement à tous ceux qui sont concernés, tout spécialement les patients.

\section{References}

1 Béique F, Ali M, Hynes $M$, et al. Canadian guidelines for training in adult perioperative echocardiography. Can J Anesth 2006; 53: 1044-60.

2 Lambert AS, Mazer CD, Duke PC. Survey of the members of the cardiovascular section of the Canadian Anesthesiologists' Society on the use of perioperative transesophageal echocardiography - a brief report. Can J Anesth 2002; 49: 294-6.

3 Leape LL, Park RE, Kahan JP, Brook RH. Group judgments of appropriateness: the effect of panel composi- tion. Qual Assur Health Care 1992; 4: 151-9.

4 Memtsoudis SG, Rosenberger $P$, Loffler $M$, et al. The usefulness of transesophageal echocardiography during intraoperative cardiac arrest in noncardiac surgery. Anesth Analg 2006; 102: 1653-7.

$5 \mathrm{Kuhl} \mathrm{HP,} \mathrm{Hanrath} \mathrm{P.} \mathrm{The} \mathrm{impact} \mathrm{of} \mathrm{transesophageal}$ echocardiography on daily clinical practice. Eur J Echocardiogr 2004; 5: 455-68.

6 Schroder JN, Williams ML, Hata JA, et al. Impact of mitral valve regurgitation evaluated by intraoperative transesophageal echocardiography on long-term outcomes after coronary artery bypass grafting. Circulation 2005; 112 (9 Suppl): I293-8.

7 Pearlman AS, Gardin JM, Martin RP, et al. Guidelines for optimal physician training in echocardiography. Recommendations of the American Society of Echocardiography Committee for Physician Training in Echocardiography. Am J Cardiol 1987; 60: 158-63.

8 Pearlman AS, Gardin JM, Martin RP, et al. Guidelines for physician training in transesophageal echocardiography: recommendations of the American Society of Echocardiography Committee for Physician Training in Echocardiography. J Am Soc Echocardiogr 1992; 5: 187-94.

9 Cabalan MK, Stewart W, Pearlman A, et al. American Society of Echocardiography and Society of Cardiovascular Anesthesiologists task force guidelines for training in perioperative echocardiography. J Am Soc Echocardiogr 2002; 15: 647-52.

10 Jones AE, Tayal VS, Kline JA. Focused training of emergency medicine residents in goal-directed echocardiography: a prospective study. Acad Emerg Med 2003; 10: 1054-8.

11 Hellmann DB, Whiting-O'Keefe Q Shapiro EP, Martin LD, Martire C, Ziegelstein RC. The rate at which residents learn to use hand-held echocardiography at the bedside. Am J Med 2005; 118: 1010-8.

12 Bruce CJ, Montgomery SC, Bailey KR, Tajik J, Seward $J B$. Utility of hand-carried ultrasound devices used by cardiologists with and without significant echocardiographic experience in the cardiology inpatient and outpatient settings. Am J Cardiol 2002; 90: 1273-5.

13 Silcox LC, Ashbury TL, VanDenKerkhof EG, Milne B. Residents' and program directors' attitudes toward research during anesthesiology training: A Canadian perspective. Anesth Analg 2006; 102: 859-64.

14 Monaghan MJ. Role of real time 3D echocardiography in evaluating the left ventricle. Heart 2006; 92: 131-6.

15 Iwakura $K$, Ito $H$, Kawano $S$, et al. Comparison of orifice area by transthoracic three-dimensional Doppler echocardiography versus proximal isovelocity surface area (PISA) method for assessment of mitral regurgitation. Am J Cardiol 2006; 97: 1630-7. 